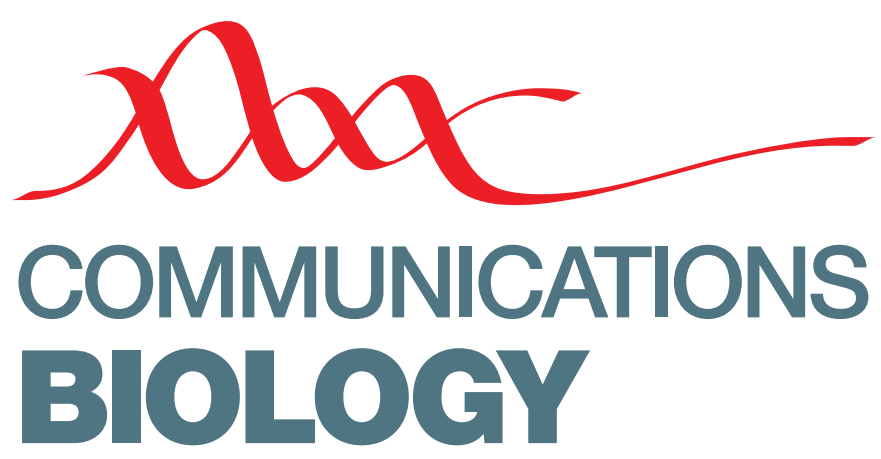

Check for updates

https://doi.org/10.1038/s42003-020-1020-3 OPEN

\title{
Author Correction: Enhanced 4Pi single-molecule localization microscopy with coherent pupil based localization
}

\section{Sheng Liu (1) \& Fang Huang (1)}

Correction to: Communications Biology https://doi.org/10.1038/s42003-020-0908-2, published online 8 May 2020.

In the original published version of the article, the link to the Figshare dataset referred to in the Data availability statement and the Supplementary Information was missing. The link is https://doi.org/10.6084/m9.figshare.11987448.v1. The errors have been corrected in the HTML and PDF versions of the article and in the 'Description of Additional Supplementary Files' PDF.

Published online: 29 May 2020

\footnotetext{
(c) Open Access This article is licensed under a Creative Commons Attribution 4.0 International License, which permits use, sharing, adaptation, distribution and reproduction in any medium or format, as long as you give appropriate credit to the original author(s) and the source, provide a link to the Creative Commons license, and indicate if changes were made. The images or other third party material in this article are included in the article's Creative Commons license, unless indicated otherwise in a credit line to the material. If material is not included in the article's Creative Commons license and your intended use is not permitted by statutory regulation or exceeds the permitted use, you will need to obtain permission directly from the copyright holder. To view a copy of this license, visit http://creativecommons.org/licenses/by/4.0/.
}

(C) The Author(s) 2020 